\title{
Precursors of the 1930 Great Indigenous Revival among the Yoruba People of Southwestern Nigeria
}

\author{
Dr. Ogunrinade, Adewale 0. \\ Mr. Ogbole, Friday Abu \\ Address: Department of Religious Studies, Faculty of Arts and Social Sciences, \\ Gombe State University, Gombe, Nigeria. \\ E.mailwalesoft@yahoo.com, Phone: 08035522497 \& 08036382200
}

\section{Doi:10.5901/jesr.2013.v3n2p149}

\section{Abstract}

Many scholarly works have been written about the 1930 indigenous Great Revival in Nigeria which bothered about its impact and successes. However, the underlying factors that contributed to its successes have not been well emphasized. These factors in this paper are referred to as precursors. This paper appraises six precursors of Aladura Revivals of 1930 in Nigeria so as to identify how they helped in the overall success of the revival. Relevant literatures about the revival were consulted. Six precursors were identified namely: Yoruba society and religion, Islam, Christian Mission, Colonial Administration, Faith Tabernacle and Cherubim and Seraphim Movement. All six precursors contributed to the success and perpetuation of the revival. The culture and worldview of the Yoruba people were important ingredients for the founders and followers of the revival for the smooth and successful take of the revival. Though Islam was a proselytizing religion, it was able to enhance the success of the Aladura revival though indirectly through certain identified similarities between it and Aladura Christianity. While the missionary oriented Christian missions and the Colonial Administration related offensively with the Aladura progenitors, Aladura mission benefited immensely from them through the experiences gained by its founders while they were with the missionary churches. The Faith Tabernacle acted as the springboard for the revival as many of the leaders of the revival were groomed in the F.T Society and they abided by its doctrines. The Cherubim and Seraphim Society being the first indigenous society to become a church among the Yoruba was connected with the revival as from 1928. The society projected some of Aladura beliefs such as prayer and exorcism. The six precursors played significant roles in the overall success of the revival. Aladura Christianity in southwestern Nigeria at the time related with the traditional religion both directly and indirectly making converts from them. These precursors created the basis for the emergence of the revivalists and the motivation for their activities among the Yoruba people of Southwestern Nigeria.

\section{Introduction}

Aladura Christianity is characterized by its emphasis on the work of the Holy Spirit, revelation and healing and re-interpreting Christianity in terms of felt needs of the local culture (D. Ayégbóyìn, and S. A. İshola. 1997). It originated as a result of the activities of one Daddy Alli who was the sexton of the St. Savior's Anglican Church, Ijebu-Ode in 1918 in Nigeria. Daddy Alli had a dream about the spiritual state of the church. He saw in his dream that the church was divided into two unequal halves whereby the bigger half was in darkness while the lesser half in light. This dream was interpreted to mean that the church's faith in God had been lukewarm and that there was the need for spiritual reawakening. He relayed it to four other members of the church namely J.B. Sadare, E.O. Odubanjo, D.C. Oduga and E.O.W. Olukoya who commenced serious prayer that led to the founding of the Prayer Band popularly known as Egbe Aladura (Praying Band). They rejected infant baptism as practiced in the Anglican Church and also refused to have connection with all forms of medicine be it western or traditional. All these resulted in a conflict between the group and the Anglican Church harboring them and they were asked to leave the Anglican Church. The Aladura movement however started as a renewal movement searching for true spirituality (Aladura 2010). 
Still in 1918, there was an epidemic which was the aftermath of the WWI that ravaged the world and Nigeria had its own share of the problem. The influenza epidemic killed a lot of people and the search of a solution was not feasible. This praying group resorted to finding a cure through prayer and they were able to save many lives through the help of the Holy Spirit who provided a spiritual cure. This strengthened the prayer group and increased its fame and population as there was the formation of many of its branches throughout Nigeria. The society which was only prayer band became known as the Precious Stone Society or Diamond Society (Egbe Okuta Iyebiye in Yoruba phraseology) in 1920 (C.O. Oshun, 1985). It later became the Faith Tabernacle due to its association with the Faith Tabernacle of Philadelphia in 1923 (S.A. Fatokun 2005). It was in July 1930 that the Great Revival started. There are however many causes for the Great Revival and some of them shall be discussed below.

\section{The Causes of Aladura Revival of 1930 Onwards}

One main figure of the revival was Joseph Ayo Babalola. His fame started to grow as from the commencement of one of the revivals that preceded the 1930 Great Revival. This revival took place at Ilofa. Also, one Daniel Ajibola who was his town mate and a Faith Tabernacle member at Ibadan was eager to introduce him to D.O. Odubanjo and other Faith Tabernacle leaders. The reason for this was that he (Daniel Ajibola) believed that there was much similarity between the teachings of Faith Tabernacle and Ayo Babalola. Babalola met D.O. Odubanjo and Pastor Esinsinade at Odubanjo's house in Lagos. During the meeting, he narrated to them his call and the theme of his evangelism. After hearing his story, they were convinced about his ministry and his usefulness if allowed to join the Faith Tabernacle. He was taken to the Lagos lagoon and was baptized by Pastor Esinsinade (A. Alokan, 1991).

A day was fixed for him to address the entire Faith Tabernacle assembly at Ebute-Elefun Headquarters, Lagos. Babalola made his "call narrative" at the forum for a period of six hours and all the brethrens were engulfed in awe. An eyewitness at the occasion says:

The news of Prophet Joseph Babalola got to Lagos and we sent to him to visit us. The whole of Lagos and Ebute-meta shook when he came. He preached a wonderful sermon that thrilled the heart to us. Several works of healing were brought to him when he was here and the Lord stretched forth His hands to heal many people from various churches. Since the days of the apostles, we have not seen such a manifestation full of great wonders of the power of God like this in this land (M.O. Idowu, 2007).

After this meeting, the whole assembly was convinced about Ayo Babalola's ministry and the leaders of the assembly were further convinced about his charismatic potentials. They saw him as an evidence of all they had believed in and hoped to see happen.

Daniel O. Orekoya, a native of Ijebuland and a tailor by profession also came to the charismatic scene of the moment through his great love for prayer. Though crippled he became a member of the Faith Tabernacle in Lagos. His distinguished qualities started to manifest such that for more than four years he was the leader of IdiOro Faith Tabernacle assembly, first as a sexton and later as the caretaker of the maternity (C.O. Oshun 1981). On 17 February 1930, he saw a vision of three angels appearing unto him. When he became afraid, the angels disappeared from his sight but he was hearing them clearly saying that the members of the Faith Tabernacle believed strongly in Jesus Christ. They further acknowledge that the members were steadfast in the practice of Divine Healing. However, they showed their unhappiness fore the sins that the members were committing (A. Alokan, 1991). The angels told him "the Lord was prepared to transform the church into a big tree under which all other trees would come for a shade". Orekoya delivered this message to the Faith Tabernacle assemblies in Lagos and Ebute- Meta. After this, he asked for financial support from them to enable him travel to other places so that he could broadcast this message to other assemblies, but his request was declined. Some of the reasons why his request was not granted included the fact that he could only read in Yoruba language and that he was not a talented visionary. In addition, he was berated as a man of small stature but older in age. Orekoya disappeared from Lagos and nobody knew his where about until he was found at Ilesa during the Oke-Ooye Revival. (C.O. Oshun 1981). Orekoya was significant in relation to this revival because he also participated

A meeting was arranged to debate certain issues involving allegations leveled against Pastor Babatope in 1929, this meeting did not hold until 9 July 1930 when the Faith Tabernacle leaders met in Ilesa. Ayo Babalola was invited to this meeting to officially introduce himself to the national leaders of the Faith Tabernacle. He was 
not a member of the group neither was he invited to contribute to the debate. Those that attended the meeting included Odubanjo, Akinyele, Esinsinade, Onasinwo, elders from the various branches of the Faith Tabernacle, and four elders from the Oyan branch that leveled the allegation against Babatope (C.O. Oshun 1981). After Babalola had introduced himself to the forum, and was permitted to narrate his evangelistic activities, he was excused for the rest of the deliberation. Such issues slated for debate included polygamy (mark 10:6ff) and optional use of western medicine as a supplement to divine healing (Deut.7:15).

\section{Precursors of the Aladura Revivals of 1930 Onward}

Here we shall consider six precursors that aided the smooth and successful take-off of the Aladura Movement that later culminated in the Aladura Revival which assumed prominence in 1930. Such factors include the following, "Traditional Yoruba Society and Religion", "Islamic Religion", "Presence of the Christian Mission in the South Western part of Nigeria" and the "activities of the Colonial Administration". Others include the "organization of the faith Tabernacle as an offshoot of the Precious Stone Society", "other Aladura Churches that sprang before the era of the Great Revival" and finally the "call to ministry of Ayo Babalola and Daniel Orekoya".

\subsection{Traditional Yoruba Society and Religion}

Aladura Revivalism started among the Yoruba people of Nigeria. Yoruba people in the southwestern part of Nigeria comprising of Lagos, Oyo, Ogun, Ondo, Ekiti, and Benin Provinces were all under the southern administration of the colonial government. These people are blessed with their own "traditional religions". The word "religions" is used because it comprised of a whole lot of different cults with "Olodumare" cementing the different cults together. No wonder, Bolaji Idowu describes the "Yoruba Religion" as "a mixed bag of individual cults" with Olodumare holding the cults together and maintaining their oneness (E. Bolaji Idowu, 1962). The divinities in traditional Yoruba Religion were many in number, ranging from 200 to 1,440. They include Sango, Osun, and Sanponna, which can be categorized as nature gods. There were also functioned deities such as Orunmila, Ogun, and Obatala. Adherents of Yoruba traditional religion worship several divinities but they worshipped each one separately (G.E. Simpson, 1980).

They believed that in matters relating to problem - solving, these divinities were ready to offer assistance and make them get over whatever messy situation they might find themselves. Therefore, Yoruba people had a "potent" way of getting over the challenges of life in the traditional way before the Aladura Revivals. When the missionaries came to Yorubaland, they "intended to pollute" the system through their disregard for the local religions of the people. This occasioned the apparent resistance they met in some parts of Yorubaland. However, since their entry in 1842, several Yoruba leaders had played host to them. Typical examples are Kurunmi and Sodeke (J.F. Ade Ajayi, 1965). The hospitality offered the missionaries made mission Christianity to get to places as Abeokuta, Badagry Lagos, Ibadan, and Ijaye and other places and thrived. Ever since their presence and their unwelcome attitude towards the culture of the people, the Yoruba Christians had been looking for a way to free themselves from the over bearing attitudes of the white missionaries. Therefore, the African Churches emerged in Lagos and began to "thrive". The reason for this is because the Yoruba religions held faith as paramount and the faith was about their gods and deities, cultures and world-view. Where the mission churches failed, the African churches "succeeded".

The Aladura churches realized that if they must succeed among the people, they must respect the rich legacies of the religion of the people, their culture, language, and social organization. The Aladura missionaries took advantage of this "golden rule" and it could be assumed that the cordial relationship between them was that both of them displayed and maintained a well robust and cordial faith stand. Aladura Christianity germinated, grew, and fruited among the people, its people, because it identified the people and interpreted its Christianity to them in their culture and language.

\subsection{Islam}

Islam also prepared the ground for the survival of Aladura Christianity and Revivalism in Yorubaland. Islam had been popular in the southwestern part of Nigeria as early as the beginning of the Twentieth Century. Most of 
the towns in Yorubaland had known the religion. The towns are Osugbo, Offa, Ilorin, Ilofa, Ikare, and Kabba (C.O. Oshun, 2000).

The geographical distribution of Muslims and Christians vary in both the north and the south blocs of Nigeria. While the north, which is predominantly Muslim, has few Christians, the southwest has equal numbers of Christians and Muslims. Because of this fair mix in population of the two religions in the southwest, Aladura Christianity was able to gain some latitude of advantage A. Omoyajowo, 1979).

Some similarities between the Aladura Christians and Islam that further removed barrier that might have estranged them and strangled the relationship existed. These common grounds include the fact that both religions, though alien to the African continent had ceased to be alien. This is because both religions have always made use of African evangelists and missionaries to propagate the faith. In addition, both religions unlike mission Christianity were not racially biased. Since the leaders and adherents of the religions are Africans, and Yoruba, conversion was easy. Furthermore, both Islam and Aladura Christianity have concepts that agree or are in harmony with the culture of the converts as both permit polygamy. In addition, both strive as much as possible to be independent of European way of life. The adherents were not under any obligation to imitate or copy the Europeans' lifestyle. Apart from the above, Islam and certain Aladura Christian denominations have certain ritual practices that are common. For example, adherents of both use flowing robes that distinguish them. They remove shoes before entering places of worship and make use of religious symbols, and they pray at set periods of the day. The use of tongues or "glossolalia" in the church could also be likened to the use of Arabic in Islam. Just as Aladura adherents believe the outburst of glossolalia enhances results, Muslims also believe that Arabic is a divine language. These similarities are sure bets for mutuality in conversion. (A. Omoyajowo, 1978).

Despite all these familiarities, some northern towns in the south of Nigeria as we have mentioned earlier are predominantly Muslims towns. However, unlike the missionaries who were not able to penetrate the northern towns before independence, the Aladura churches were successful in evangelizing these domains after independence. The reason for this was that the Aladura churches had serious encounters in such places that had been captured by Islam revivalism. Both religious groups in the areas rose to the task of employing aggressive conversion strategies, which mission Christianity lacked. Still, we cannot totally blame Mission Christianity for failing to make impact in such towns. This was because the colonial policy of religious intolerance against Christian Mission in the North persisted until 1931 (E.P.T. Crampton, 2004). As soon as this policy lapsed, there was bound to be competition for converts and consolidation of territories among all religious faiths.

\subsection{The Christian Missions}

The activity of the missionaries in Yorubaland is also a factor to consider when identifying the precursors of the Aladura Revivals. The effectiveness, which accompanied the works of the missionaries, led to the religion having firm root in the areas of its domains. These areas were jealously guided and machineries were put in place to scare away intruders. Intruders in this regard included any form of spirituality different from the one obtained and permitted by the mission churches. The adventures of the Aladura patriarchs especially when traced from the "prayer-bands" or prophetic movements show that despite the resistance of the mission Churches to this insurgence, the Aladura leaders came out of them. The personnel that came out of the mission churches were resourceful. They were those who could have been more useful to the mission if they had stayed (C.O. Oshun 2000). They included catechists, lay readers, and ordained personnel who were well experienced in their different areas. Their departure from the mission churches and the attendant loss it meant translated into gains for the newly established Aladura churches and prophetic movement such as we have mentioned earlier on.

However, despite these apparent losses, there were still avenues of cooperation and mutuality especially during the Aladura Revivals. The Aladura churches are greatly indebted to the Mission Churches for at least the training their founders received from them. This is because while the Aladura dream was yet to hatch, the pioneering leaders were still in the Mission houses and churches receiving training about discipleship. Therefore, the mission churches served as the training ground and springboards for Aladura Evangelism. 


\subsection{Colonial Administration}

Aladura evangelism started in Nigeria during the Colonial Administration, precisely during the British Colonial Administration. The administrators used the indirect rule system obtained in Britain on the Yoruba people. Here, the different "Native Administrators" were under their respective native rulers or Obas who in turn reports to the colonial administrators at either district or provincial level (C.O. Oshun 2000). These Obas were however lenient with their subjects including the Aladura leaders that they are expected to be watching over. Those appointed watchdogs protected the Aladura leaders over them. Therefore, in the face of persecution and oppression, these local rulers were tempering justice with kindness (D. Ayégbóyìn, and S. A. İshola. 1997).

\subsection{The Faith Tabernacle}

The Faith Tabernacle was that group formed in 1922. Due to the excommunication of the Precious Stone Society members from St. Savior's Anglican Church Ijebu-Ode, the PSS was attracted by the Pentecostal standpoint of the Faith Tabernacle, Philadelphia, which appeared to satisfy their spiritual yearnings now. This group built upon the Precious Stone Society's consciousness of prayer and Divine Healing as the only solution to the problems and challenges of man. The fulcrum on which the Aladura Christianity and revivalism stabilized was modeled when the Precious Stone Society group became the Faith Tabernacle. It was the firm beliefs and standpoint developed then that concretized their faith especially when the beliefs of the group was put to test concerning issues about divine healing without the use of medicine.

The Faith Tabernacle, known for its doctrines of effective prayer, prophecy, ethical rigorism, biblical faith, adult baptism, divine healing and Christian fellowship was endeared to many people. The church offered the needed protection to Aladura patriarchs and their ideologies at that period when opposition abounded. The Faith Tabernacle Church stood by the idea and nurtured it. (D. Ayégbóyìn, and S. A. İshola. 1997).

\subsection{The Cherubim and Seraphim Society}

The founders of this group, came together to initiate the society in 1925 after their incidental meeting. Orimolade, due to his house-to-house itinerancy, effective prayers, soul-moving preaching and healing ministry drew much awareness and stirred the appetite of people towards prophetic ministry. The society was well entrenched in the southwest area of Nigeria and later connected with the Great Revival that took place as from 1928 (A. Omoyajowo, 1978). Cherubim and Seraphim Church exhibits some uniqueness in relation to displaying syncretistic elements in their practices where they combine traditional and Christian beliefs so as to make members feel at home. Such practices are demonstrated in prayer, marriage, spiritual agencies, church service, language and interpretation of revelation (D. Ayégbóyìn, and S. A. İshola. 1997). We shall only explain three of these practices namely prayer and marriage and spiritual agencies. These syncretistic elements in the church provided a ground upon which Aladura spirituality founded its basis.

About prayer, the modus operandi of saying prayers is similar to the traditional method whereby methodical categorization of prayer and prayer elements/instruments are carefully engaged to get desired results. For instance, there are specific psalms to overcome enemies, achieve success in endeavors, fertility in marriage and averting imminent danger or death. They also give out specified instruction as to how specific prayers are to be said. For example, praying a specific prayer for a specified number of times, in the night, privately and nakedly or reading specific psalms in specified number of times and reciting certain holy names.

About marriage, the church accommodates the African system of polygamy. As a result of this, members were and are drawn from the core traditional society who were previously engaged in polygamy and were not ready to dump this system. Apart from this, clergies of the church are also allowed to have more than one wife.

Concerning spiritual agencies, the members and the leaders of the church believe in the existence of destiny and that human destiny is controlled, changed or regulated by spiritual agencies. The church asserts that it could decipher the presence of evil spirit and identify their evil intents. It claims that evil spirits are capable of causing discomfort, ill-luck, diseases, barrenness and sterility. In order to suppress the evil powers, exorcism is practiced like in African traditional religion whereby leaders of the church cast out evil spirits from members. 
All these methods employed are antecedents of the 1930 Great indigenous Revival where cases about the African spiritual worldview were squarely encountered and dealt with. The church had previously created the avenue of drawing adherent of the traditional religion into Christianity before the revival, subsequently the leaders of the revival benefitted from this initiative to win numerous converts. Cherubim and Seraphim Church through its belief in these spiritual agencies drew closer adherents of African traditional religion who saw a trace of what they believed being practiced in the Christian fashion.

\section{Conclusion}

This paper has so far reflected the six precursors of the 1930 indigenous Great Revival and how they contributed to the overall success of the revival. The six precursors: Yoruba society and religion, Islam, Christian Mission, Colonial Administration, Faith Tabernacle and Cherubim and Seraphim Movement all played significant roles in the forthcoming conversion activities that took place during the revival and the establishment of churches after the revival.

\section{References}

Ade Ajayi, J.F. 1965. Christian Mission in Nigeria 1841-1891: The Making of a New Elite. London: Longman Group Ltd. Aladura from http://www.worldlingo.com/ma/enwiki/en/Aladura\# Christ_Apostolic_Church. Retrieved in August 2010 Alokan, A. 1991. The Christ Apostolic Church (1928-1988), İbàdàn: İbùkúnolá Printing Nig. Ltd.

Ayégbóyìn, D. and. İshola. S. A. 1997. African indigenous churches: An historical perspective, Lagos: Greater Height Publications.

Bolaji Idowu, E. 1962. Olodumare: God in Yoruba Belief, London: Longman.

Crampton, E.P.T. 2004. Christianity in Northern Nigeria, Jos: Africa Christian Textbooks.

Fátókun, S.A. 2005. Pentecostalism in southwestern Nigeria with emphasis on the Apostolic Church, 1931-2001. Ph.D Thesis Dept. of Religious Studies. University of İbàdàn.

Idowu, M. O. The Great Revival of 1930: The Origin of Modern-day Pentecostalism in Nigeria, Ikeja: Divine Artillery Publications.

Metuh, E.I. Ed. The gods in retreat: continuity and change in African religions. Enugu: Fourth Dimension Publishing Co.

Omoyajowo, A. 1978. "The Aladura Churches in Nigeria since Independence", in Fashole Luke (ed.), Christianity in Independent Africa, Ibadan: Ibadan University Press.

Omoyajowo, A. 1978. Cherubim and Seraphim: The History of an African Independent Church, New york: Nok Publishers Ltd.

Òshun, C.O. 1981. Christ Apostolic Church of Nigeria: a suggested Pentecostal consideration of its historical, organizational and theological developments, 1918-1975. Ph.D Thesis. Exeter University.

Oshun, C.O. 1983. The Pentecostal Perspective of the Christ Apostolic Church. Orita. 15. 2.

Òshun, C.O. 1985. The Aladura movement and their impact on Nigerian society.

Oshun, C.O. "Aladura Revivals: Apostle Babalola's Challenge to Christian Missions". Inaugural Lecture delivered at the Lagos State University, Oyo, Lagos, on the 26th July, 2000.

Simpson, G. E. 1980. Yoruba Religion and Medicine in Ibadan, Ibadan: Ibadan University Press. 